\title{
POTENSI GAS SERPIH FORMASI PULOBALANG, CEKUNGAN KUTAI, KALIMANTAN TIMUR
}

\author{
AHMAD HAMDANI ${ }^{1}$, DARDJI NOERADI $^{1}$, YUSUP ISKANDAR $^{2}$ \\ 1. Program Studi Teknik Geologi, Fakultas Ilmu dan Teknologi Kebumian, Institut Teknologi Bandung \\ (ITB), Jl. Ganesha No.10, Bandung, Jawa Barat, Indonesia, Email:ahmad.hamdani.h@gmail.com \\ 2. Pusat Survey Geologi, Badan Geologi, ESDM, Jl. Diponegoro No. 57, Bandung, Jawa Barat, Indonesia.
}

\begin{abstract}
Sari - Cekungan kutai telah terbukti sebagai cekungan migas yang produktif dan memiliki potensi yang besar, hal tersebut mengindikasikan bahwa sistem petroleum yang ada telah berjalan dengan baik. Namun, seiring dengan kebutuhan akan energi fosil, perlu dilakukan penyelidikan yang lebih khusus, terutama dalam pengembangan cadangan hidrokarbon non-konvensional. Selain itu penyelidikan ini juga ditujukan untuk mengetahui secara rinci karakteristik batuan yang berpotensi sebagai pembawa potensi gas serpih di Cekungan Kutai. Data yang digunakan dalam penelitian ini meliputi 5 (lima) sumur pengeboran, yaitu Ramin-1, Rasamala-1, Buat-1, Busang-1, dan Murung1 yang berisi data log tali kawat, log lumpur pengeboran, analisis biostratigrafi, dan geokimia beserta 81 lintasan seismik 2 dimensi. Penafsiran lebih lanjut menggunakan data geokimia dan pemodelan dengan Metode Passey. Sedangkan dalam pemodelan data geomekanika digunakan log tali kawat yang menghasilkan nilai modulus young, rasio poisson, dan indeks kegetasan batuan. Hasil analisis dan pemodelan menunjukan bahwa unit batuan Formasi Pulobalang di daerah penelitian terendapkan pada lingkungan deltaik hingga lereng paparan (slope), dengan jenis kerogen tipe III, tingkat kekayaan buruk-istimewa dengan nilai TOC antara 0.12-7\%, dan nilai kegetasan 0.05-0.971. Dengan total potensi gas serpih mencapai 2,78 TCF.
\end{abstract}

Kata kunci: Cekungan Kutai, gas serpih, geokimia, geomekanika, Passey, Miosen Awal, nonkonvensional, Fm. Pulobalang.

\begin{abstract}
Kutai Basin has proven to be a productive basin and has great potential, this fact indicating the existing petroleum system has been running well. Therefore, more specific investigations need to be carried out, especially for development of non-conventional hydrocarbon reserves, and find out in detail the characteristics of rocks that have potential to be carriers of potential shale gas in the Kutai Basin. The used data in this study included 5 (five) drilling wells, Ramin-1, Rasamala-1, Buat-1, Busang-1, and Murung-1 which contained wireline log data, mud logs, biostratigraphic analysis, geochemical analysis, and 81 line 2-D seismik trajectories. Further interpretation using geochemical data and modelling with Passey Method. In geomechanical data analysis, modeling used wireline logs, produce Young modulus values, Poisson ratios, and rock brittleness. Petrophysical analysis was used to be a parameter of rock quality. These data are depicted vertically and horizontally with seismic data benchmark, resulting in facies distribution and rock quality parameters as shale gas reservoirs. The research showed that Pulobalang Formation in the study area, deposited in the deltaic to slope environment, with type III kerogen, TOC content level poor until excellent with 0.12 - 7\% value and brittleness value 0.05-0.971. The calculation was conducted based standard criteria as shale gas reservoir. Total potential of shale gas resources in the Pulobalang Formation reaches 2.78 TCF.
\end{abstract}

Key words: Early Miocene, geochemistry, geomechanics, Kutai Basin, shale gas, Passey Method, unconventional.

\section{Pendahuluan}

Ekplorasi migas yang dilakukan di Kalimantan Timur dan Selat Makasar telah dilakukan sejak akhir abad ke-19, dengan cara memetakan rembesan-rembesan minyak yang terdapat di permukaan. Kegiatan tersebut menghasilkan penemuan bahwa persebaran rembesan minyak terjadi di sepanjang jalur Balikpapan sampai dengan Utara Samarinda, yang dikenal sebagai wilayah Antiklinorium

\section{Samarinda.}

Pengeboran eksplorasi pertama dilakukan di sumur Louise-1 (1897) dan Mathilde-1 (1898), yang keduanya terbukti menghasilkan minyak dan dengan cepat berkembang menghasilkan lapangan-lapangan yang baru di sekitarnya. Pada awal abad ke-20 penurunan produksi minyak dan gas bumi diikuti dengan 
peningkatan kebutuhan manusia akan energi. Untuk mengatasi semua permasalahan tersebut, dilakukanlah berbagai kegiatan dan penggunaan berbagai macam metode eksplorasi hidrokarbon di Indonesia. Selain itu, pencarian sumber energi hidrokarbon non-konvensional juga semakin dikembangkan, salah satunya adalah gas serpih. Berdasarkan pengertian, gas serpih merupakan gas yang dihasilkan dari batuan induk berupa serpih kemudian matang dan terperangkap di dalam batuan tersebut (Sosrowidjojo, 2011). Gas yang dihasilkan akan terperangkap dan tersimpan didalam pori-pori mikro dalam lapisan serpih.

Perekahan hidraulik kemudian dikembangkan sebagai metode untuk membuka porositas dan permeabilitas yang sangat kecil pada lapisan serpih. Perekahan hidraulik dilakukan dengan cara injeksi fluida yang memiliki tekanan tinggi kedalam lubang bor, proses tersebut akan menghasilkan ketidakstabilan pada lapisan batuan yang menjadi target, sehingga akan membuka rekahan-rekahan baru di sekitarnya, rekahan ini yang membuat peningkatan porositas dan permeabilitas pada batuan, sehingga gas yang berada pada lapisan serpih dapat mengalir (Michael, 2016).

Objek dan lokasi penelitian berada pada fasies serpih berumur Miosen pada Cekungan Kutai (Gambar 1). Data yang digunakan berupa data $\log$ sumur, data seismik, geokimia, petrologi, dan laporan sumur. Penelitian dilakukan bersama Pusat Survey Geologi dengan lokasi penelitian terletak di Kabupaten Kutai dan Kota Samarinda.

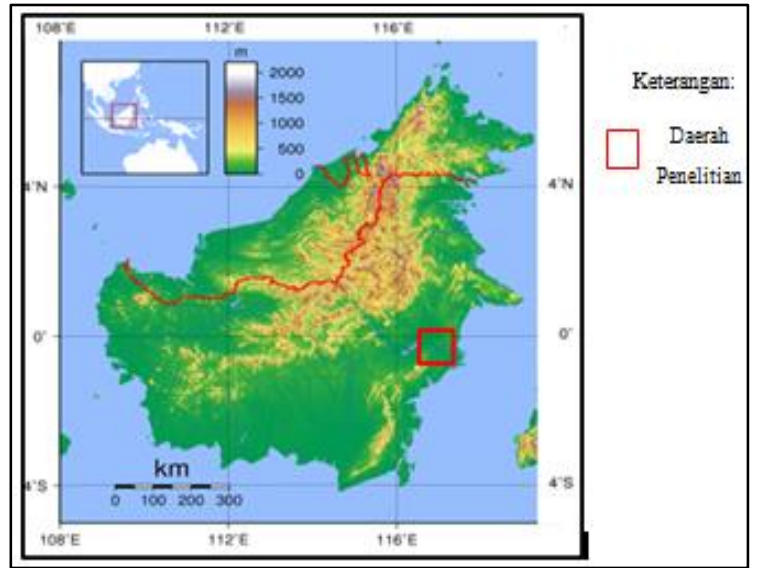

Gambar 1. Lokasi daerah penelitian.

\section{Data dan Metodologi}

Data tersedia yang digunakan dalam penelitian ini yaitu:

1. Data sumur berupa log lumpur, deskripsi serbuk bor, log talikawat, dan analisa lab dari 5 sumur.

2. Data seismik terproses sebanyak 81 lintasan, dengan total panjang $1.493 \mathrm{~km}$ (Gambar 2).

3. Analisa laboratorium geokimia berupa kandungan total karbon organic (TOC), pirolisis rock eval, dan reflektansi vitrinit (Ro).

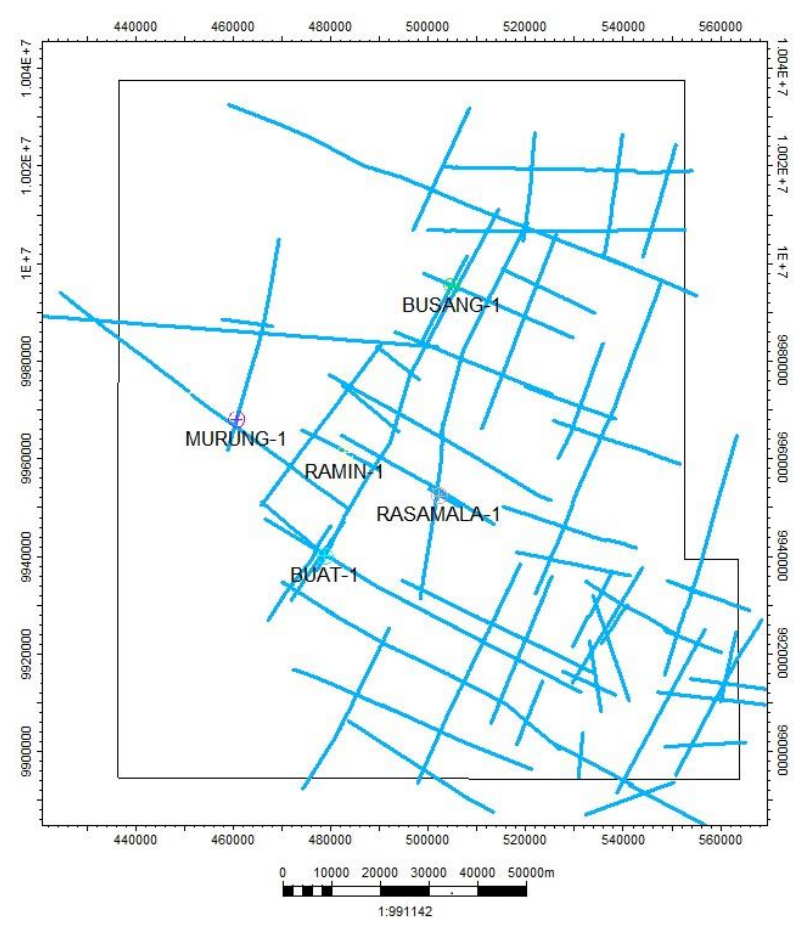

Gambar 2. Ketersediaan data seismik di daerah penelitian. 
Penelitian dimulai dengan melakukan pengujian serpih sebagai batuan induk secara umum baik dari sisi petrologi maupun dari aspek geokimia, dilanjutkan korelasi stratigrafi untuk membatasi batas formasi dan geometri dari serpih di daerah penelitian dengan dibantu oleh penarikan horizon seismik untuk menggambarkan kondisi geologi secara menyeluruh di bawah permukaan, dengan keluaran berbentuk peta struktur kedalaman dan peta ketebalan. Penafsiran lingkungan pengendapan dilakukan dengan menggunakan laporan sumur, biostratigrafi, pengamatan inti bor, serta analisis bawah permukaan.

Analisis selanjutnya yaitu pemodelan petrofisika yaitu analisis kegetasan batuan, bertujuan untuk mendapatkan properti batuan dan geomekanika di daerah penelitian, analisis dilakukan dengan menghitung indeks kegetasan pada interval Formasi Pulobalang mengunakan metode Wang dan Gale (2007), berdasarkan nilai Modulus Young dan nisbah Poisson dari serpih. Analisis geokimia batuan induk mencakup analisis material organik (TOC), Rock Eval, dan Ro yang kemudian digunakan untuk mengetahui kualitas dan kuantitas batuan induk. Dalam melakukan pemodelan TOC, digunakan Metode Passey, yakni dengan menggunakan hubungan antara respon nilai log sonik, log resistivitas, dan log sinar gamma (Gambar 3), dengan divalidasi oleh data geokimia yang didapatkan dalam laporan sumur.

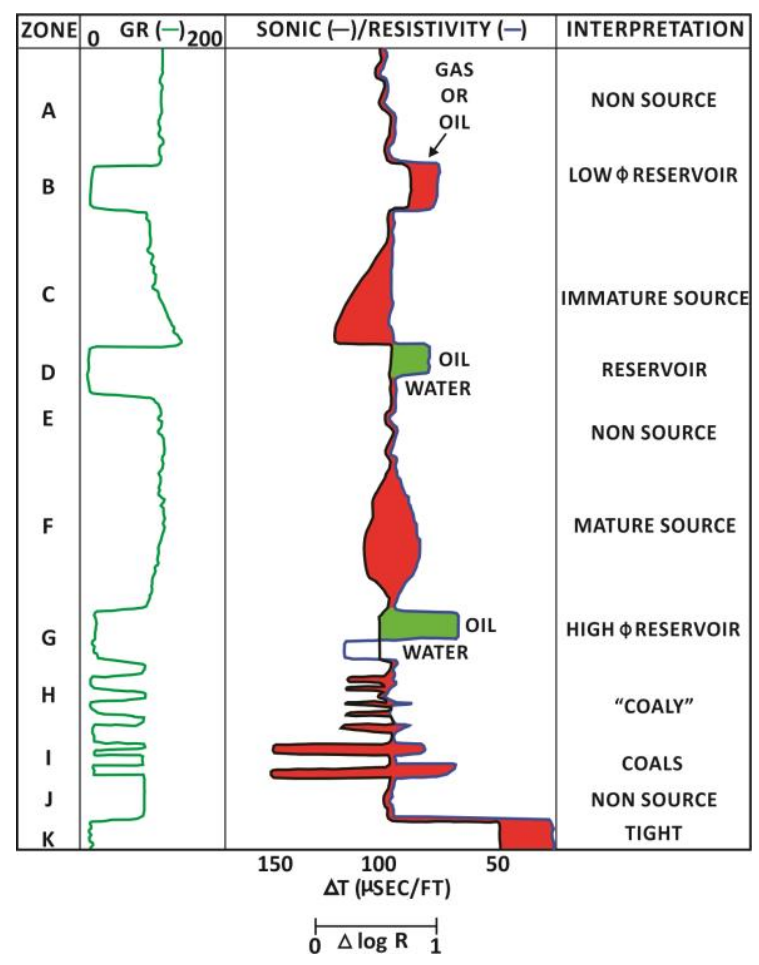

Gambar 3. Panduan skematis untuk interpretasi berbagai fitur yang diamati pada overlay $\Delta \log R$ (Passey dkk., 1990).

Tahapan integrasi data yang telah didapatkan, hasil analisis dan pengolahan data tersebut kemudian ditarik kesimpulan secara induksi sehingga diperoleh hasil yang konklusif mengenai hubungan antara fasies serpih, lingkungan pengendapan yang mengontrol kekayaan dan kegetasan, serta potensi dari serpih sebagai reservoir gas serpih di daerah penelitian.

\section{Hasil Penelitian}

Korelasi dilakukan pada sumur yang tersedia, bertujuan untuk membatasi batas-batas formasi di daerah penelitian. Dasar yang dilakukan dalam korelasi adalah dengan menarik berdasarkan umur dengan menggunakan panduan data elektrofasies dan biostratigrafi yang didapat dari laporan. Secara umum sumur-sumur di daerah penelitian memiliki kedalaman pengeboran yang dangkal, sehingga tidak menembus lapisan-lapisan yang berumur sangat tua. Ketebalan sedimen akibat pengendapan yang sangat cepat juga memiliki andil keterbatasan variasi lapisan yang ditembus oleh 
pengeboran sumur di daerah penelitian. Berdasarkan analisis biostratigrafi yang dilakukan, interval terdalam yang berhasil ditembus pada penelitian ini berada pada Miosen Awal (N4-N8). Kemudian umur termuda adalah N12 pada sumur Buat-1.

Korelasi sumur dilakukan berdasarkan umur Miosen pada sumur-sumur di daerah penelitian dengan tujuan mencari hubungan stratigrafi diantara sumur-sumur. Korelasi dilakukan dengan penampang berarah utaraselatan melewati sumur Buat-1, Ramin-1, dan Busang-1 (Gambar 4) dan barat-timur melewati sumur Murung-1, Ramin-1, dan Rasamala-1 (Gambar 5), hasil korelasi menunjukan pola pengendapan mengasar dan menebal ke atas mencirikan pengendapan pada lingkungan transisi-laut dangkal. Hal tersebut menunjukan perkembangan cekungan di daerah penelitian dengan proses progradasi sedimen dalam pengendapan sedimen post-rift.

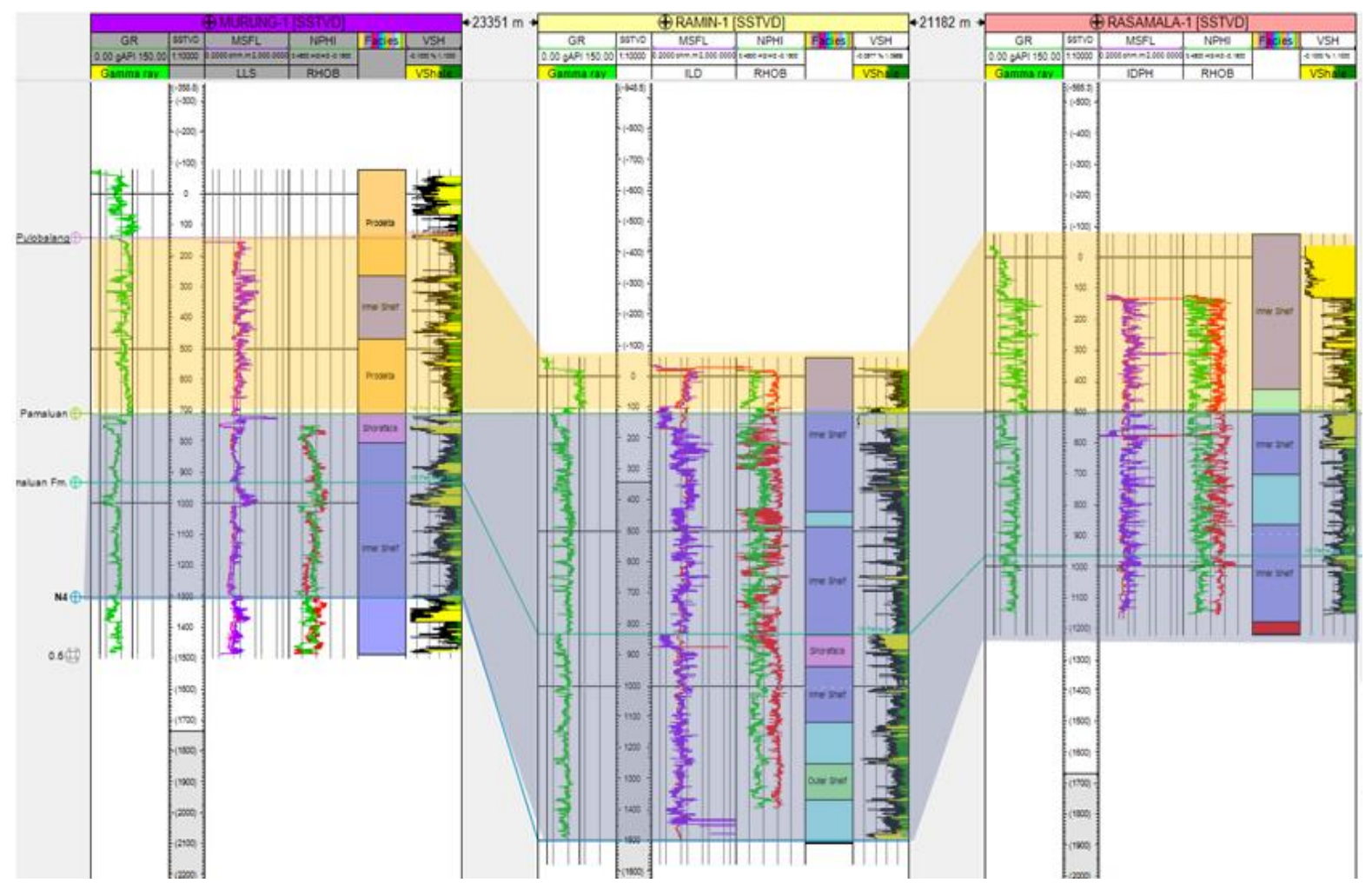

Gambar.4 Korelasi dilakukan dengan penampang berarah utara-selatan melewati sumur Buat1, Ramin-1, dan Busang-1 


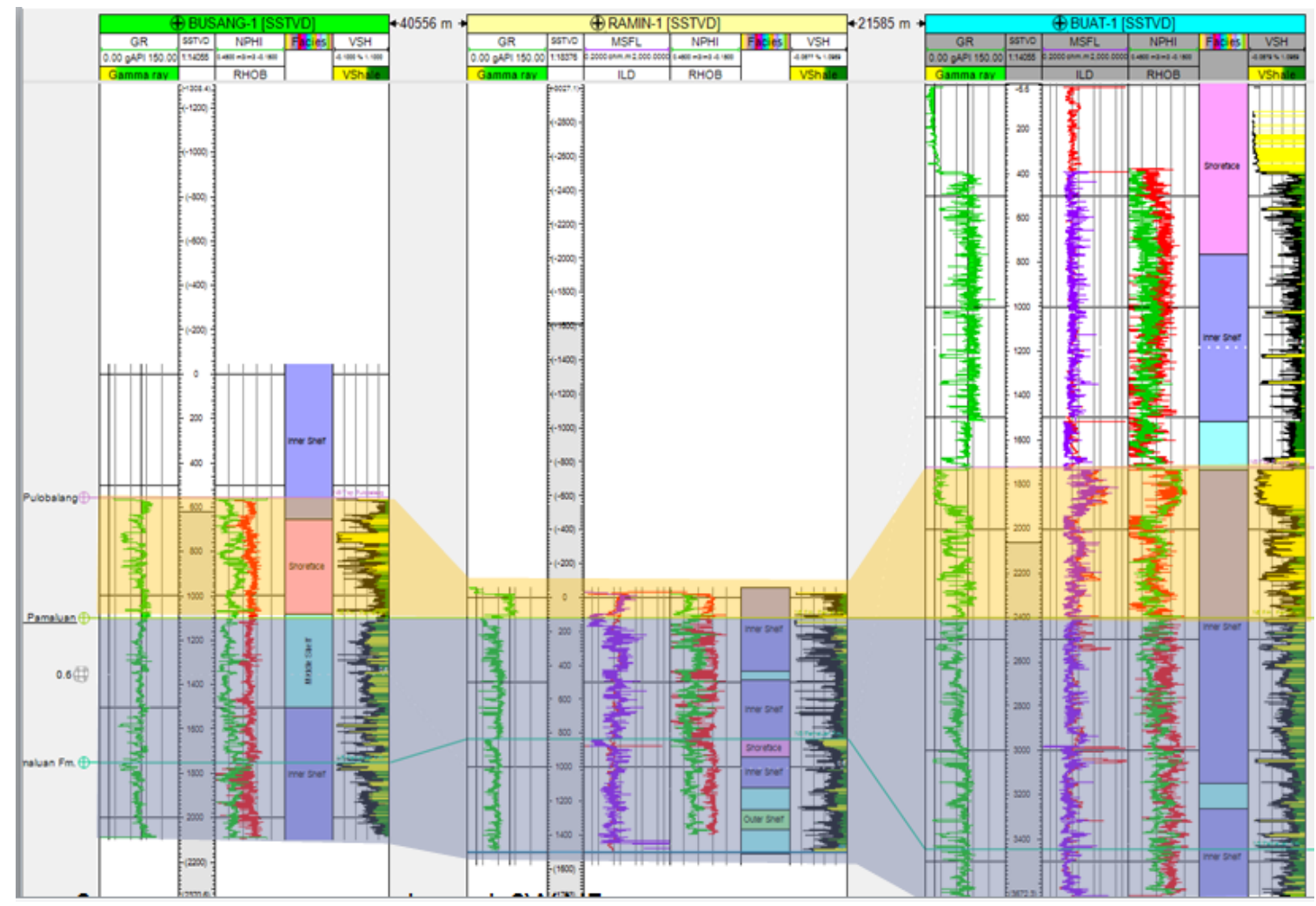

Gambar.5 Korelasi dilakukan dengan penampang berarah barat-timur melewati sumur Murung1, Ramin-1, dan Rasamala-1.

Interpretasi seismik berupa penarikan horizon dan sesar pada 81 lintasan seismik 2D, kemudian dilanjutkan pembuatan peta struktur waktu dan peta struktur kedalaman, bertujuan untuk memberikan gambaran secara utuh kondisi bawah permukaan di daerah penelitian. Peta struktur kedalaman secara umum pada semua interval umur menunjukan terjadi pendalaman kearah tenggara (SE) (Gambar 6). Fenomena ini menunjukan pergerakan rifting dari selat makasar yang semakin bergerak ke timur, menghasilkan ruang akomodasi di sebelah timur daerah penelitian. Struktur geologi yang terbentuk di daerah penelitian berupa sesar naik dan lipatan. Pola struktur yang terlihat memiliki sumbu berarah timurlaut (NE)-baratdaya (SW), dan di tengah daerah penelitian terlihat struktur antiklin yang dikenal sebagai Antiklinorium Samarinda membentuk tinggian lokal di daerah penelitian.

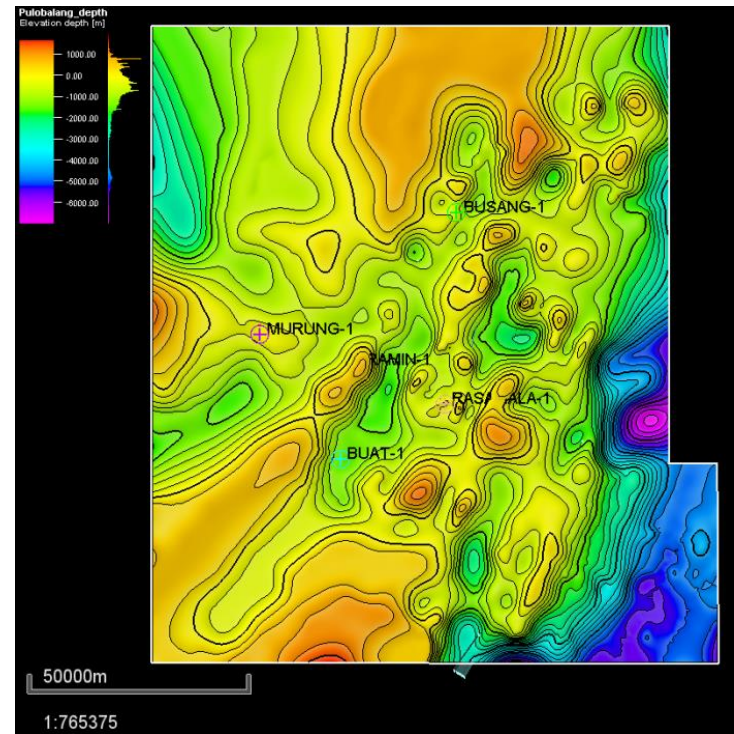

Gambar 6. Peta Struktur kedalaman Formasi Pamaluan.

Hasil analisis menunjukan terjadi penebalan sedimen dari bagian barat daerah penelitian hingga ke bagian tengah, kemudian menipis pada bagian tenggara (Gambar 7). Perubahan ini diinterpretasikan karena terjadi perubahan ruang akomodasi pada cekungan karena pengangkatan pada bagian barat daerah 
penelitian diiringi terjadinya susut laut sehingga sedimentasi semakin bergerak kearah cekungan (progradasi). Penipisan sedimen disebabkan terjadinya perubahan sudut pada lingkungan lereng.

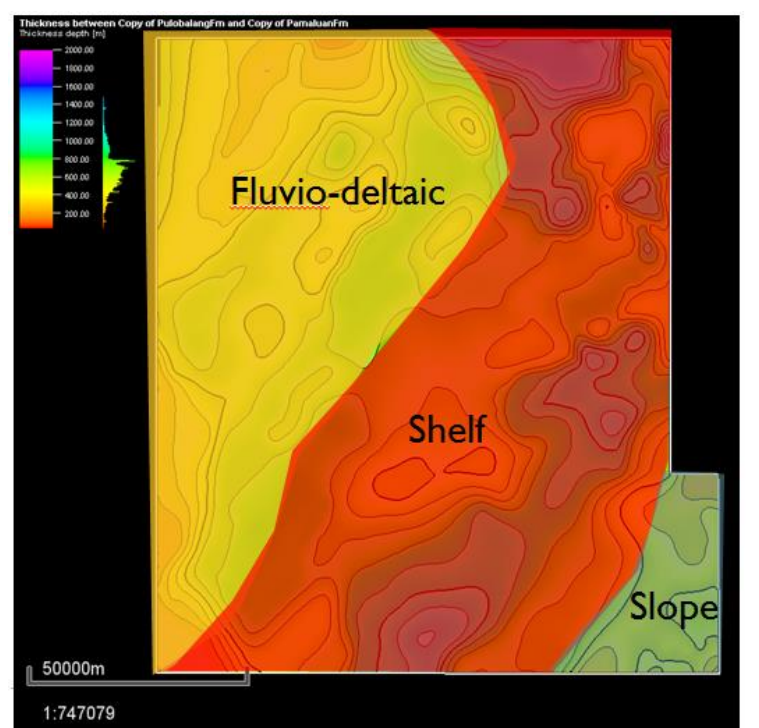

Gambar 7. Peta Struktur ketebalan Formasi Pamaluan ditumpang-tindih dengan lingkungan pengendapan.

\section{Pemodelan TOC Passey}

Dalam melakukan analisis geokimia dengan Metode Passey, data log sinar gamma, log sonik dan log resistivitas digunakan sebagai acuan. Pada interval serpih, plot data log sonik dan log resistivitas akan menunjukan separasi yang diterjemahkan menjadi estimasi kandungan material organik. Pada sumur Ramin-1 nilai TOC berkisar antara $0,19-5,2 \%$ WT. menunjukan batuan berkualitas buruk hingga istimewa (Gambar 8).

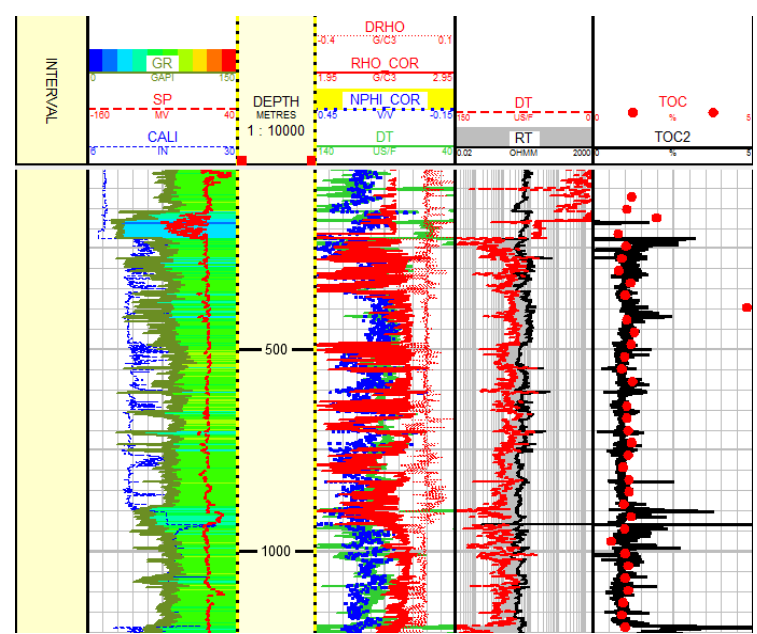

Gambar 8. Hasil pemodelan Metode Passey pada sumur Ramin-1.

\section{Pemodelan Geomekanika}

Sifat kegetasan adalah suatu parameter mekanika dalam keteknikan batuan yang menunjukan hubungan antara compressive strength dan tensile strength, atau kecenderungan suatu batuan untuk patah (failure) ketika diberikan gaya. Hubungan antara sifat keteknikan batuan dengan pengembangan reservoir gas serpih menunjukan bahwa semakin getas sifat suatu batuan maka akan memudahkan untuk dilakukan perengkahan. Hal ini berkaitan dengan proses produksi. Aspek geomekanika yang digunakan diantaranya Modulus Young dan Nisbah Poisson.

Pada sumur Rasamala-1 nilai kegetasan yang didapat berkisar antara 0,42 - 0,96 dengan nilai rata-rata 0,57 . Analisis dari pola kegetasan yang ditunjukan melalui perhitungan menunjukan bahwa secara umum nilai kegetasan akan meningkat. Seiring dengan pengendapan ke arah umur lebih muda (Gambar 9). Peningkatan BI sejalan dengan bertambahnya proporsi fasies batupasir, hal ini disebabkan kandungan kuarsa yang meningkat akan meningkatkan nilai modulus young. Pola perubahan ini juga tercermin di dalam sejarah tektonik di daerah penelitian yakni pada kala Miosen Awal terjadi penurunan muka air laut, yang diiringi progradasi pengendapan sedimen-sedimen post rift menutupi cekungan (van de Weerd dan Armin, 1992). 


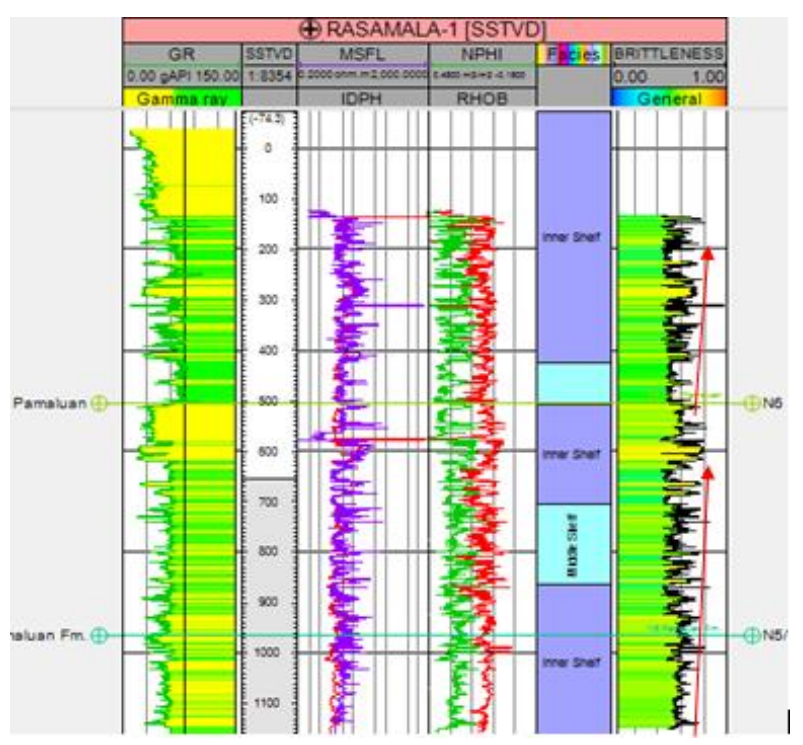

Gambar 9. Hasil pemodelan Geomekanika pada sumur Rasamala-1.

Hasil pemodelan menunjukan bahwa nilai kegetasan batuan di daerah penelitian masuk kedalam katagori less brittle sampai brittle.

\section{Penyebaran Properti}

Dalam melakukan pemodelan fasies di daerah penelitian dilakukan pembagian fasies berdasarkan shaliness $\left(\mathrm{V}_{\text {shale }}\right)$ dengan cut off $\mathrm{V}_{\text {shale }}>0,5$, perhitungan $\mathrm{V}_{\text {shale }}$ telah dilakukan sebelumnya pada analisis petrofisika. Nilai $\mathrm{V}_{\text {shale }}$ lebih dari 0,5 akan menghasilkan fasies shale, dan $\mathrm{V}_{\text {shale }}<0,5$ diinterpretasikan sebagai fasies batupasir. Penyebaran fasies di daerah penelitian juga menggambarkan kondisi lingkungan pengendapan dan cerminan dari paleogeografi tempat batuan tersebut diendapkan. Fasies batupasir di sebelah barat laut di daerah penelitian kemudian secara berangsur berubah menjadi fasies dengan dominan serpih semakin ke arah tenggara (Gambar 10).

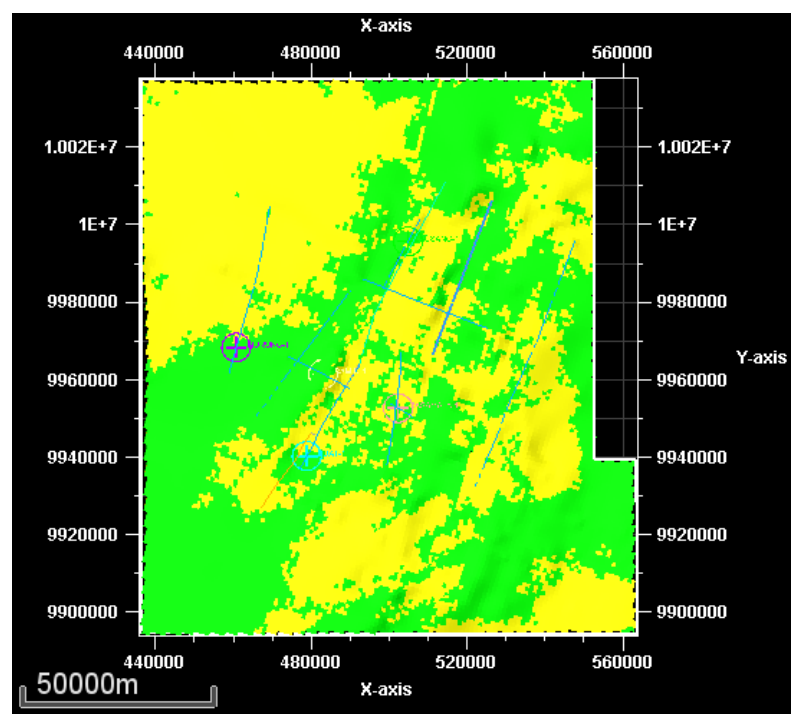

Gambar 10. Penyebaran Fasies di daerah penelitian.

Terlihat penyebaran $\mathrm{V}_{\text {shale }}$ akan mengikuti pola lingkungan pengendapan dengan ukuran butir semakin halus ke arah tenggara sebagai akibat perubahan lingkungan pengendapan dari delta ke lereng-laut terbuka (Gambar 11). Perubahan porositas menunjukan kecilnya nilai porositas yang menyusun batuan, dengan penyebaran mengikuti tren fasies serpih, yaitu di bagian tengah penelitian hingga kearah tenggara (Gambar 12). Pola penyebaran yang terlihat memiliki kecenderungan yang hampir sama, penyebaran nilai saturasi air akan mengikuti fasies batuan yang ada, dengan kondisi yang jenuh dengan air (Gambar 12).

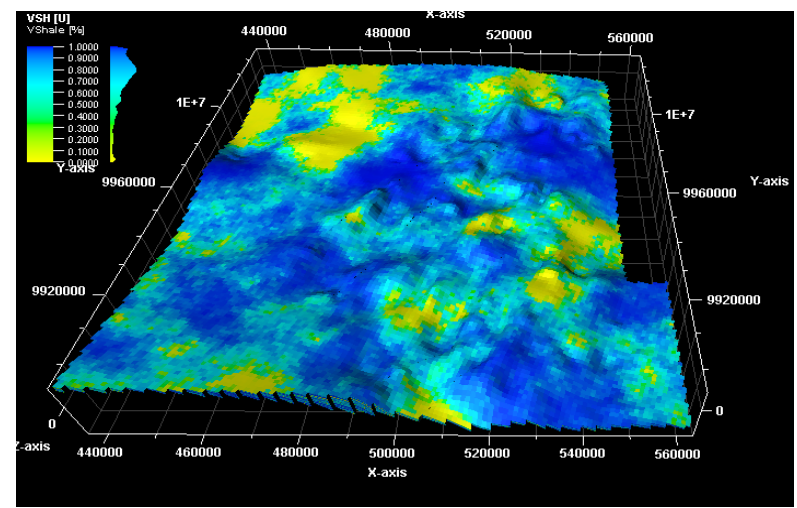

Gambar 11. Penyebaran volume serpih di daerah penelitian. 


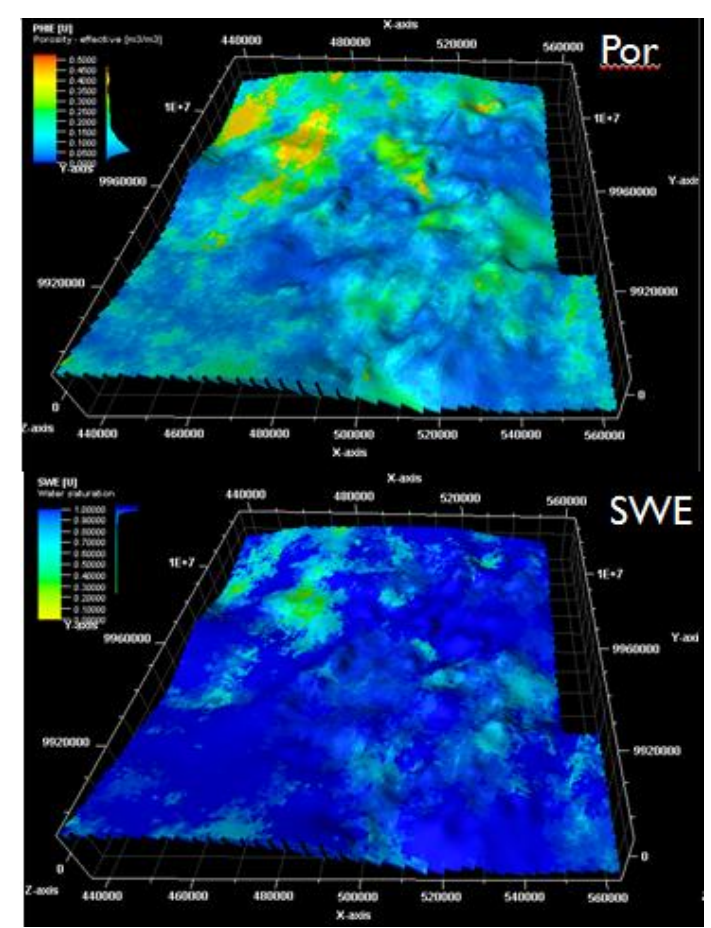

Gambar 12. Penyebaran porositas (atas) dan SWE (bawah) pada Formasi Pulobalang.

Secara umum nilai BI yang didapatkan memiliki tren yang tinggi semakin dekat kearah daratan nilai BI diantara 0.6-0.91, dikarenakan kandungan kuarsa yang melimpah. Di daerah penelitian kandungan TOC termasuk buruk-istimewa dengan rentang 0,2-4,27 \% pada Formasi Pulobalang (Gambar 13).

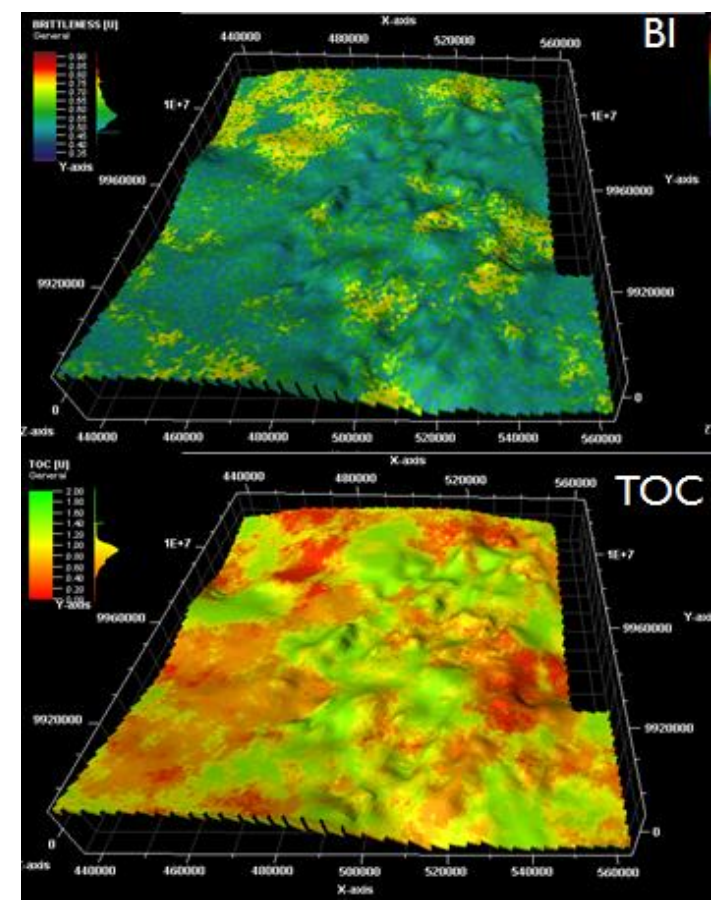

Gambar 13. Penyebaran BI (atas) dan TOC (bawah) pada Formasi Pulobalang.
Analisis kematangan yang dilakukan di daerah penelitian dilakukan dengan melakukan pemodelan sejarah pemendaman, dengan validasi data Ro yang tersedia pada laporan sumur. Kondisi kematangan di daerah penelitian memiliki level yang berbeda di tiap sumur, hasil pemodelan menunjukkan kematangan berada pada 1100-2000 meter dengan batasan pantulan vitrinit > 0,6.

\section{Perhitungan Cadangan}

Penentuan daerah menarik dalam penelitian ini mengacu pada Chinn, 1991. Dengan memperhitungkan kandungan TOC lebih dari $1 \%$, berada dalam perioda generasi gas (Gas Window), memiliki kandungan mineral getas lebih dari 48\%, dan ketebalan efektif 30-50 m (ketika lapisan serpih tersebut menerus, dan $>50$ m ketika tidak menerus).

Dengan prasyarat tersebut maka dilakukan analisis daerah menarik dengan mengintegrasikan parameter-parameter yang sebelumnya telah dibuat dalam bentuk peta persebaran menjadi peta sweet spot/potensi

Dalam peta persebaran zona yang memenuhi kriteria pemanfaatan gas serpih berada pada daerah berwarna kuning yang memiliki pola semakin banyak ke arah cekungan /basin atau semakin menjauh dari darat.

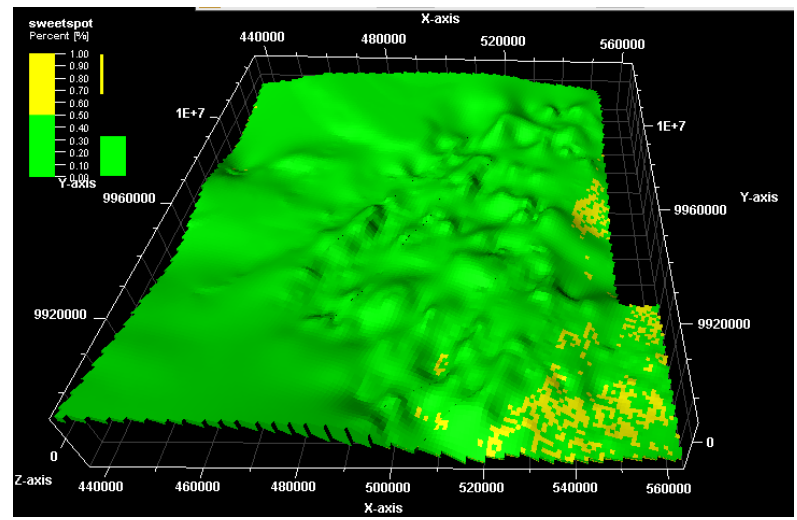

Gambar 14. Zona menarik potensi gas serpih di daerah penelitian.

Gas in place merupakan hasil penjumlahan nilai gas teradsorpsi dan gas bebas, hal ini dikarenakan dalam batuan serpih hidrokarbon akan tersimpan di dalam pori batuan atau rekahan, dan sebagian besar akan teradsorpsi pada permukaan bahan organik. Sumberdaya 
gas serpih di daerah penelitian dihitung dengan menjumlahkan total kandungan gas bebas dan gas terabsorpsi. Perhitungan gas bebas dilakukan menggunakan rumus Ambrose dkk. (2010). Sedangkan Metode Jarvie (2007), digunakan untuk menghitung kapasitas gas teradsorpsi (Ga). Metode ini dilakukan karena pada penelitian ini tidak dilakukan analisis Langmuir Isoterm, perhitungan $\mathrm{Ga}$ menggunakan pendekatan grafik perbandingan TOC dan kandungan gas.

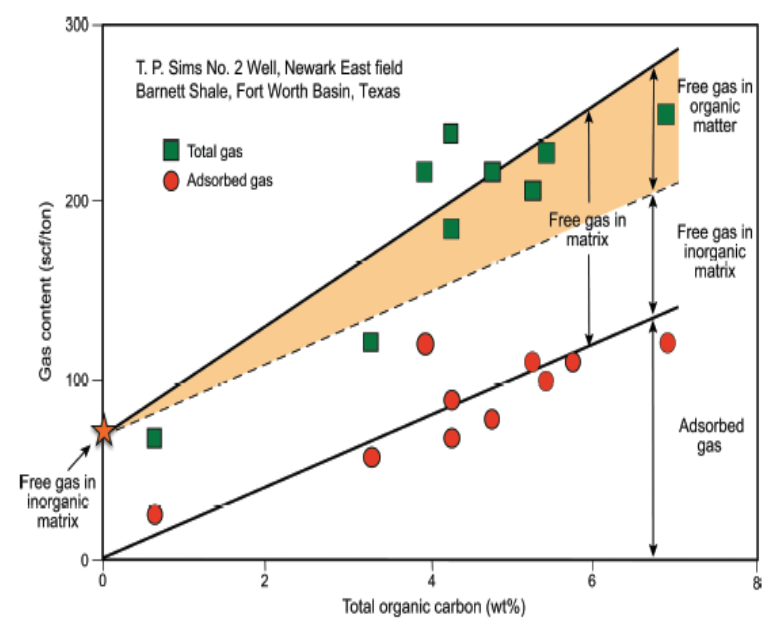

Gambar 15. Grafik perbandingan TOC dan Ga.

$$
\begin{aligned}
& G f=43.560 \mathrm{Ah} \phi(\mathrm{I}-\mathrm{Sw} / \mathrm{Bg}) \\
& G s=1359,7 \mathrm{~A} h \rho b \mathrm{Ga} \\
& \begin{array}{ll}
\text { Gs } & : \text { Gas Teradsorpsi In Place, TCF } \\
\mathrm{Gf} & \text { : Gas Bebas In Place, TCF } \\
\mathrm{Ga} & : \text { Adsorbed gas storage capacity. } \\
\mathrm{GCF} & \\
\mathrm{SCF} / \mathrm{ton} & : \text { Interest area.acre } \\
\mathrm{A} & : \text { ketebalan, feet } \\
\mathrm{h} & : \text { Bulk density, g/cm3 } \\
\rho b & : \text { Porosity. } \% \\
\phi & : \text { Saturasi air } \\
\mathrm{Sw} & : \text { volume gas, faktor formasi }
\end{array}
\end{aligned}
$$

Perhitungan dengan menggunakan formula tersebut untuk Adsorb gas dikombinasikan dengan perhitungan free gas. Menghasilkan total sumberdaya gas serpih di daerah penelitian mencapai 28,15 TCF.

\section{Kesimpulan}

Berdasarkan hasil penelitian dan analisis yang telah dilakukan, maka dapat ditarik beberapa kesimpulan yaitu sebagai berikut:

1. Formasi Pulobalang di Cekungan Kutai memiliki tingkat kekayaan material organik yang bervariasi mulai dari buruk-istimewa, dengan nilai TOC 0,2-4,27\%.

2. Tipe kerogen di cekungan kutai pada formasi berumur Miosen Awal merupakan tipe III yang cenderung mengasilkan gas, dengan zona kematangan berada pada kedalaman dangkal diantara 1100-2000 meter.

3. Nilai kegetasan pada lapisan batuan di Formasi Pulobalang memiliki nilai BI diantara 0,6-0,91.

4. Total potensi sumberdaya gas serpih pada Formasi Pulobalang mencapai 2,78 TCF.

\section{REFERENCES}

Chinn, E.W. (1991): The role of organic geochemistry in petroleum exploration, Basin Research Institute Bulletin, Louisiana State University.

Jarvie, D. M., Hill, R. J., Ruble, T. E., dan Pollastro, R. M. (2007): Unconvential shale-gas systems : The Mississipian Barnett shale of North-Central Texas as one for thermogenic shale-gas assessment: AAPG Bulletin, 91, pp. 475- 499.

Michael, A. (2016): Hydraulic fracturing optimation: experimental investigation of multiple fracture growth homogeneity via perforation cluster distribution, The University of Texas Austin.

Passey, Q. R., Creaney, S., Kulla, J. B., Moretti F. J., Stroud J. D. (1990): A practical model for orogenic richness from porosity and resistivity logs, The American Association of Petroleum Geologist Bulletin, 74.

Perez, R. dan Marfurt, K. (2013): Calibration of brittleness to elastic rock properties via mineralogy logs in unconventional reservoirs, $A A P G$ International Conference and Exhibition, Cartagena, Colombia.

Sosrowidjojo, I. B. (2011): Organic geochemistry: Geographic location of crude oils based on biomarker 
compositions of the Sunda-Asri Basins, International Journal of the Physical Sciences, Indonesia, 6 (31), 7291 - 7301.

Tim Rekomendasi WK MNK Kutai PSG, (2017): Laporan akhir rekomendasi wilayah kerja migas nonkonvensional Cekungan Kutai, Provinsi Kalimantan Timur, Bandung, Indonesia.

van de Weerd, A. A. dan Armin, R.A., (1992): Origin and evolution of the tertiary hydrocarbon-bearing basins in Kalimantan (Borneo), Indonesia, AAPG bulletin, 76 (11), 1778-1803.

Wang, F. P. dan Gale, J. (2009): Screening criteria for shale-gas systems. Gulf Coast Association of Geological Societies 58th Annual Convention, 27-29 September, Shreveport, LA.

Waples, D. W. (1985): Geochemistry in petroleum exploration, International HumanResources Development Corporation, Boston, p. 232. 